\title{
Life-history traits of wild honey bee colonies living in forests around Ithaca, NY, USA
}

\author{
Thomas D. SEELEY \\ Department of Neurobiology and Behavior, Cornell University, Ithaca, NY 14853, USA \\ Received 7 December 2016 - Revised 27 February 2017 - Accepted 12 May 2017
}

\begin{abstract}
Wild honey bee colonies - both truly wild (in trees and buildings) and simulated wild (in small hives) - were studied to determine their life-history traits, to see if these traits have changed now that these colonies are infested with Varroa destructor. Most colonies (97\%) survive summers, but only 23\% of founder (first-year) colonies and 84\% of established colonies survive winters. Established colonies have a mean lifespan of 5-6 years and most (87\%) have a queen turnover (probably by swarming) each summer. A population model shows that these life-history traits produce a stable population of colonies. Remarkably, the suite of colony life-history traits found in the 2010s (with $V$. destructor ) matches that found in the 1970 s (without $V$. destructor ). It seems likely that the wild colonies living near Ithaca, NY, possess defenses against $V$. destructor that are not costly.
\end{abstract}

Apis mellifera / life-history evolution / colony survival/deformed wing virus / Varroa destructor / wild honey bees

\section{INTRODUCTION}

Starting in 1952 in Europe and in 1987 in North America, colonies of the hive honey bee (Apis mellifera) became infested with an ectoparasitic mite (Varroa destructor) (reviewed by Locke 2016). Researchers found that if a colony of European-derived honey bees is not treated for $V$. destructor, then in a year or two, the colony's mite population will surge, the bees' virus titers will skyrocket, and the colony will die (Korpela et al. 1992; Fries et al. 2006). It was widely believed, therefore, that the wild colonies of European-derived honey bees living in Europe and North America had perished (Moritz et al. 2007; Potts et al. 2010).

In the mid 2000s, however, reports began to surface from Europe and North America of populations of wild colonies of European-derived honey bees that are surviving despite being infested

Corresponding author: T. Seeley, tds5@cornell.eduD.

Seeley, tds5@cornell.edu

Manuscript editor: Yves Le Conte with $V$. destructor: Sweden (Fries et al. 2006), France (Le Conte et al. 2007), and the USA (Seeley 2007). A balanced relationship between honey bees and $V$. destructor is expected wherever most colonies are living wild because in these places, there should be strong natural selection for mite-resistant bees, and maybe also for avirulent pathogens and parasites. The expectation of strong natural selection on the bees was confirmed recently by a study (Mikheyev et al. 2015) of the wild honey bees living around Ithaca, NY. It used whole-genome sequencing of bees collected from wild colonies in 1977 (before arrival of $V$. destructor) and in 2011 (after arrival of $V$. destructor) and found that 232 nuclear genes scattered throughout the genome underwent strong selection between the sampling dates. This study also found that these bees experienced a collapse in effective population size between 1977 and 2011, probably the result of massive colony mortality following the arrival of $V$. destructor in the mid 1990s. The census population size has, however, recovered (Seeley 2007).

This paper shifts from the genetics to the ecology of the wild colonies living around Ithaca, NY. 
It reports a 7-year study (2010-2016) of how this population is surviving even though all colonies are infested with $V$. destructor . A study conducted 40 years ago (1974-1977) found that wild colonies living around Ithaca possessed a certain suite of life-history traits: slow development, long lifespan, and few but costly offspring (Seeley 1978). The present study sees if the life-history traits of these colonies have changed since the 1970s because now they must invest in immunological, behavioral, and other defenses against $V$. destructor and the viruses that this mite vectors. Presumably, the costs of these additional defenses are traded off against other fitness components - reviewed by Minchella (1985), Sheldon and Verhulst (1996), and SchmidHempel (2003) — so it may be that wild colonies now have slower development, shorter lifespan, or fewer (or less costly) offspring. Another possibility, though, is that wild colonies have low-cost defenses against the mites and viruses. If so, then their life-history parameters are expected to be unchanged. To find out which scenario pertains to the wild colonies living around Ithaca, NY, I studied 33 nest sites (in trees and buildings) occupied by wild colonies and 22 hives occupied by simulated wild colonies.

\section{MATERIALS AND METHODS}

\subsection{Study area and bees' ancestry}

This study is based on colonies living in the heavily forested countryside south of Ithaca, NY, USA ( $\left.42^{\circ} 26^{\prime} 36^{\prime \prime} \mathrm{N} 76^{\circ} 30^{\prime} 0^{\prime \prime} \mathrm{W}\right)$. This region was settled in the early 1800 s and until the late 1800 s the region was devoted primarily to agriculture. It is no longer farmed, and large acreages that were once cultivated have grown into forests ranging from old-field successional forests to mature forests. It has a moderate continental climate: summers are short and warm (temperatures rarely exceed $32^{\circ} \mathrm{C}$ ); winters are long and cold (temps often reach $-18^{\circ} \mathrm{C}$ ). The ancestry of the wild colonies has been analyzed (Mikheyev et al. 2015). Both old (1977) and modern (2011) populations are primarily descendants of Central European races (Apis mellifera carnica and $A$. $m$. ligustica), but also have a sizable ancestry from Western European (A. m. mellifera) and Central Asian (A.m. caucasica) races.

\subsection{Finding wild colonies}

Thirty-three nest sites of wild colonies were followed; 14 were found by bee hunting (Seeley 2016) and 19 were found by chance. As before (Seeley 1978), I distinguished two categories of colonies: founder and established. Founder colonies are ones that have not yet survived a first winter; established colonies are those that have. I categorized a colony as founder or established only if the owner of the tree or building housing the colony reported that it had moved into the site that summer (hence a founder colony), or had lived there the previous summer and had survived the previous winter (hence an established colony). All other colonies were categorized as "ambiguous". A founder or ambiguous colony that survived winter was reclassified as an established colony the following spring.

\subsection{Inspecting nest sites and statistical analyses}

I inspected each nest site three times a year: spring, summer, and fall. Spring inspections were made before May 10, thus before the main swarming season. Summer inspections were made after July 20, thus after the main swarming season. Fall inspections were made after September 20, thus after the secondary swarming season. In the Ithaca area, $80 \%$ of swarms are produced between 15 May and 15 July and 20\% between 15 August and 15 September (Fell et al. 1977). Flying bees at a nest entrance are not proof of a live colony; they can be robbers or scouts examining a dead colony's nest. My criterion of a live colony was bees entering a nest with pollen loads. I continued to inspect nest sites where colonies had died, to measure reoccupation rates, except for five sites that were damaged (e.g., two cavities in a cabin's walls were torn open by a black bear, Ursus americanus ).

To test for differences between summer and winter in probability of colony survival, I pooled the counts of colonies that survived or died during each season (summer or winter) for all 7 years, in 
a table with summer/winter, founder/established, and survived/died axes (see Appendix 1 Table IV). These data were analyzed separately for summer and winter colonies, testing for homogeneity between founder and established in the proportion of surviving colonies, using Fisher's exact test. This test assumes independence among years in colony survival. This assumption is supported by large year-to-year differences in weather conditions and in colony genetics (section 3.6). Colonies might develop increasing loads of parasites and pathogens over time, which might violate the assumption of independence of colony survival data among years, but colonies did not show decreasing likelihood of survival with increasing age.

\subsection{Estimating average lifespan of wild colonies}

I estimated the average colony lifespan using the probabilities of colony survivorship. To do so, I summed over all ages the product of each age times the probability of death at that age, and added 1 year to convert from age at death to lifespan. (One adds a year because age at death is less than lifespan.) The probability of death at each age was calculated by multiplying the probability of colony survival to that age and the probability of colony death at that age (see Seeley 1978). To estimate average lifespan of colonies that survived the risky first year (= established colonies), I performed the calculations just described, but with 1.00 as the survival probability for year 1 .

\subsection{Establishing simulated wild colonies}

Over three summers (2011-2013), 35 simulated wild colonies were established using natural swarms: 19 collected while clustered on branches, 15 caught in bait hives in forests, and 1 found in an empty hive. Each hive consisted of a solid bottom board; a "wood bound Varroa screen" (Dadant and Sons, Hamilton, IL); a Langstroth hive body with 10 frames; a wooden inner cover; and a telescoping outer cover (Figure 1). The Varroa screen was used to get mite-drop counts. Colonies had combs like in a natural nest (Seeley

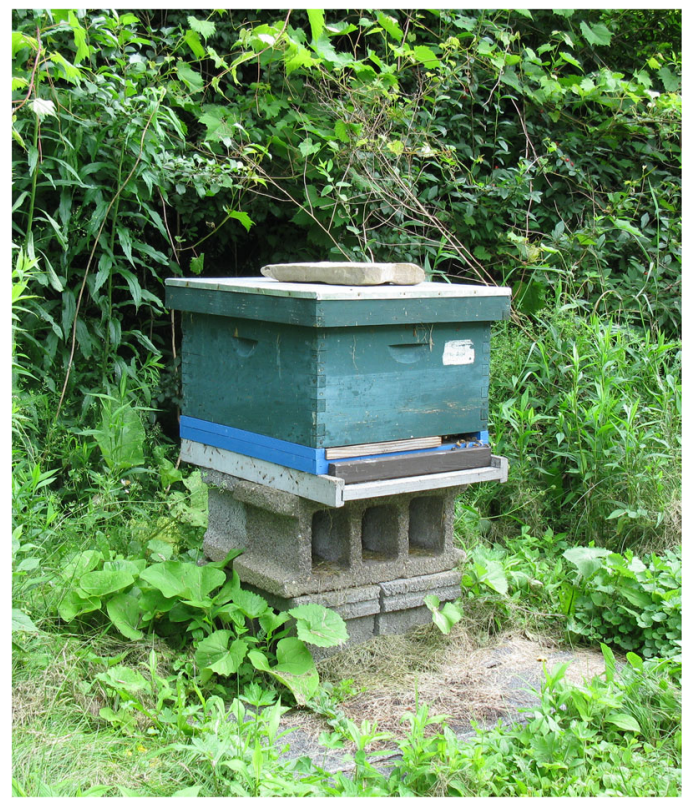

Figure 1. Sample hive used for housing simulated wild colonies. Without mice excluder.

and Morse 1976). Each hive was equipped with eight frames filled with worker comb frame, and two frames without comb (so colonies had space to build drone comb). The empty frames were in positions 2 and 9. Each hive's entrance was a 22$\mathrm{cm}^{2}$ opening, the modal size for natural nests (Seeley and Morse 1976). Each hive sat in a sunny spot with its entrance facing south, ca. $0.3 \mathrm{~m}$ off ground, and covered with 1/2" (13 mm) mesh hardware cloth to exclude mice. One week after installing a swarm in a hive, I labeled its queen with a paint mark (POSCA water-based paint marker, Mitsubishi Pencil Co.), to track queen turnover.

\subsection{Inspecting simulated wild colonies and statistical analyses}

To measure colony longevity and colony state, I inspected each simulated wild colony three times a year: early May, late July, and late September. In each inspection, I examined the colony's combs and I noted: (1) colony alive or dead, (2) color of queen's paint mark, (3) presence or absence of wax moths (Galleria mellonella), and (4) presence or absence of brood diseases: chalkbrood 
(causative agent: Ascosphaera apis), American foulbrood (Paenabacillus larvae), European foulbrood (Streptococcus pluton), or sacbrood (sacbrood virus). Diseased brood were identified visually by reference to Hansen (1987). Queens without paint marks were given marks in color appropriate for year. After each inspection, I installed a gridded sticky board (Dadant and Sons, Hamilton, IL, USA) beneath the colony's Varroa screen, to see how many $V$. destructor mites would drop onto it over $48 \mathrm{~h}$.

To test for differences between summer and winter in probability of colony survival, I pooled the counts of colonies that survived or died during each season (summer or winter) for all 6 years, in a table with summer/winter, founder/established, and survived/died axes (see Appendix 2 Table V). These data were analyzed separately for summer and winter colonies, testing for homogeneity between founder and established in the proportion of surviving colonies, using Fisher's exact test. I assumed independence among years in colony survival, for the reasons stated above.

\section{RESULTS}

\subsection{Wild colony nest sites and survivorship}

Figure 2 shows for each of the 33 nest sites (1) when the site was added to the study, (2) what site type it was, (3) how long each colony was alive, and (4) when each site vacated by colony death was reoccupied. Most (61\%) were in trees; the rest (39\%) in buildings. Fifty-three colonies occupied the 33 sites.

Table I shows colony survivorship probabilities for each year. Over 7 years, I made 105 checks of colony survival over summer (26 of founder colonies and 79 of established colonies) and 85 checks of colony survival over winter (20 founder and 65 established). Both founder and established colonies had higher probabilities of survival over summer than winter (founder: $p=1.00$ vs. 0.23 , $p<0.0001$; established: $p=0.97$ vs. 0.84 , $p<0.0105)$. Table I also shows that founder and established colonies did not differ in probability of summer survival ( $p=1.00$ vs. $0.97, p<0.58$ ), but that founder colonies relative to established colonies had a much lower probability of winter survival ( $p=0.23$ vs. $0.84, P<0.0001)$.

\subsection{Wild colony lifespan}

The average probabilities of colony survivorship for summer and winter were used to estimate the average lifespan of colonies. Using $p=(1.00 \times 0.23)=0.23$ for probability of firstyear survival (as founder colony), and $p=(0.97 \times 0.84)=0.81$ for probability of survival for subsequent years (as established colony), I estimate 2.2 years for average lifespan of colonies overall (founder and established). Making the same calculation, but for established colonies only, I estimate 6.2 years for average colony lifespan.

\subsection{Nest-site reoccupations by wild colonies}

Figure 2 shows there were 31 instances when the May inspections revealed that a colony had died over winter. Each death created a vacant nest site furnished with combs and perhaps honey and pollen. Many were reoccupied (21 out of $31,67 \%$ ), and often quickly (16 reoccupations occurred in first summer site was vacant, 3 in second summer, and 2 in third summer).

\subsection{Simulated wild colony survivorship}

Figure 3 shows for each of 22 hives when it was added to the study, how long each colony was alive in its hive, and how quickly each hive was reoccupied following colony death. In total, 35 swarms occupied these hives over the five summers.

Table II shows the colonies' survivorship probabilities for each year of the study. Over the 6 years, 73 checks were made of colony survival over summer (35 founder colonies and 38 established colonies) and 73 checks were made of colony survival over winter (35 founder colonies and 38 established colonies). Both founder and established colonies had higher probabilities of survival over summer than winter (founder: $p=1.00$ vs. $0.57, p<0.0001$; established: $p=1.00$ vs. $0.79, p<0.006$ ). 


\begin{tabular}{|c|c|c|c|c|c|c|c|c|}
\hline Site & Type & $\begin{array}{l}2010 \\
\text { M J S }\end{array}$ & $\begin{array}{l}2011 \\
\text { M J S }\end{array}$ & $\begin{array}{r}2012 \\
\text { M J S }\end{array}$ & $\begin{array}{r}2013 \\
\text { M J S }\end{array}$ & $\begin{array}{r}2014 \\
\text { M J S }\end{array}$ & $\begin{array}{r}2015 \\
\text { M J S }\end{array}$ & $\begin{array}{l}2016 \\
\text { M J S }\end{array}$ \\
\hline Arnot Oak & $\mathrm{T}$ & & & & & & & \\
\hline Lick Brook Poplar & $\mathrm{T}$ & & & & & & & \\
\hline Lounsbery House & $B$ & & & & & & & \\
\hline Caroline Cabin - E & $B$ & & & & & & & \\
\hline Caroline Cabin - N & $B$ & & & & & & & \\
\hline Kohout Walnut & $\mathrm{T}$ & & & & & & & \\
\hline Henry House - W & $B$ & & & & & & & \\
\hline Zeman Lab-W & $B$ & & & & & & & \\
\hline Darlington Pine & $\mathrm{T}$ & & & & & & & \\
\hline Park Preserve Pine & $\mathrm{T}$ & & & & & & & \\
\hline Arnot Sugarbush & $\mathrm{T}$ & & & & & & & \\
\hline Arnot Banfield Cr. & $\mathrm{T}$ & & & & & & & \\
\hline Arnot Reckn. Hill & $\mathrm{T}$ & & & & & & & \\
\hline Arnot Irish Hill & $\mathrm{T}$ & & & & & & & \\
\hline Redman Pine & $\mathrm{T}$ & & & & & & & \\
\hline Eddy Farm Pine & $\mathrm{T}$ & & & & & & & \\
\hline Zeman Lab - E & $B$ & & & & & & & \\
\hline Ruina House & B & & & & & & & \\
\hline Buttermilk Falls & $B$ & & & & & & & \\
\hline Level Green Ash & $\mathrm{T}$ & & & & & & & \\
\hline Brookton Mkt. & B & & & & & & & \\
\hline Central Chapel Hs. & . $B$ & & & & & & & \\
\hline Treman Hemlock & $\mathrm{T}$ & & & & & & & \\
\hline Mulholland Sycam. & . $T$ & & & & & & & \\
\hline Armstrong Apple & $\mathrm{T}$ & & & & & & & \\
\hline Trumansburg Oak & $\mathrm{T}$ & & & & & & & \\
\hline Baker Inst. Barn & $B$ & & & & & & & \\
\hline E. Hill Locust & $\mathrm{T}$ & & & & & & & \\
\hline Zeman Lab - S & $B$ & & & & & & & \\
\hline Henry House - N & $B$ & & & & & & & \\
\hline Nyrop Maple & $\mathrm{T}$ & & & & & & & \\
\hline Mt. Pleasant Pine & $\mathrm{T}$ & & & & & & & \\
\hline Hurd Woods Maple & $\mathrm{T}$ & & & & & & & \\
\hline
\end{tabular}

Figure 2. Results from a 7-year program of inspecting 33 nest sites occupied by wild colonies. Inspections made in early May, late July, and late September. Colored bars indicate type of colony that occupied a site: Blue = founder colony, Green = established colony, Gray = ambiguous colony (see section 2). Red indicates dead colony, so site no longer occupied. White indicates site removed from study because it was damaged and no longer provided a home site.

The two types of colonies did not differ in probability of survival over summer $(p=1.00$ vs. $1.00, p=1.00)$, but founder colonies relative to established colonies had a lower probability of survival over winter ( $p=0.57$ vs. $0.79, p<0.0764)$. 
Table I. Survivorship probabilities of wild colonies over summers and winters, for 2010-2016

\begin{tabular}{|c|c|c|c|c|c|}
\hline \multicolumn{3}{|c|}{ Summer } & \multicolumn{3}{|l|}{ Winter } \\
\hline \multicolumn{3}{|c|}{ (10 May-20 Sept) } & \multicolumn{3}{|c|}{ (20 Sept-10 May) } \\
\hline Year & Founder & Established & Year & Founder & Established \\
\hline 2010 & nd & $1.00(n=7)$ & 2010-2011 & nd & $1.00(n=7)$ \\
\hline 2011 & nd & $1.00(n=11)$ & 2011-2012 & nd & $0.73(n=11)$ \\
\hline 2012 & $1.00(n=3)$ & $1.00(n=14)$ & $2012-2013$ & $0.33(n=3)$ & $0.79(n=14)$ \\
\hline 2013 & $1.00(n=6)$ & $0.79^{\mathrm{a}}(n=14)$ & 2013-2014 & $0.29(n=7)$ & $0.82(n=11)$ \\
\hline 2014 & $1.00(n=7)$ & $1.00(n=11)$ & 2014-2015 & $0.29(n=7)$ & $0.82(n=11)$ \\
\hline 2015 & $1.00(n=3)$ & $1.00(n=11)$ & 2015-2016 & $0.00(n=3)$ & $0.91(n=11)$ \\
\hline 2016 & $1.00(n=7)$ & $1.00(n=11)$ & 2016-2017 & nd & nd \\
\hline Mean & 1.00 & 0.97 & Mean & 0.23 & 0.84 \\
\hline
\end{tabular}

nd no data

${ }^{a}$ Three colonies were killed, two by a black bear that tore open nests in a cabin's walls, and one by a storm that blew over a tree.

\subsection{Simulated wild colony lifespan}

The average probabilities of colony survivorship for summer and winter were used to estimate the average lifespan of simulated wild colonies. Using $p=(1.00 \times 0.57)=0.57$ for the probability of firstyear survival (as founder colony) and $p=(1.00 \times 0.79)=0.79$ for the probability of survival for subsequent years (as established colony), I estimate 3.2 years for average colony lifespan overall (founder and established). Making the same calculation, but for established colonies only, I estimate 5.3 years for average colony lifespan.

\subsection{Queen turnover in simulated wild colonies}

Figure 3 shows that established colonies were monitored for 38 colony-summers, and that there were 33 times when an unmarked queen was found and then labeled with a new color. The annual probability of queen turnover in these colonies was $33 / 38=0.87$.

\subsection{Mite-drop counts in simulated wild colonies}

Figure 3 shows 177 mite-drop counts for the 35 simulated wild colonies. Figure 4 shows the distribution of these counts. Most (141 out of $177=80 \%)$ were low $(0-29$ mites $/ 48 \mathrm{~h})$, but some were high. Colonies with mite-drop counts below 30 mites/48 h had nearly zero mortality, but colonies with mite-drop counts above 30 mites $/ 48 \mathrm{~h}$ suffered higher mortality, reaching $100 \%$ when count was $90+$ mites $/ 48 \mathrm{~h}$.

Figure 3 also shows a relationship between queen turnover (swarming) and end-of-summer mite-drop count. The September counts are much lower for colonies with queen turnover $(23 \pm 17$ mites/48 h, $n=33$ ) than those for colonies without queen turnover (122 \pm 75 mites $/ 48 \mathrm{~h}, n=5)(t$ test; $t(36)=6.92, p<0.0001)$.

\subsection{Disease and wax moths in simulated wild colonies}

The incidence of disease, other than Varroa and associated viruses, was low. Only chalkbrood was found, and in only 4 of 35 colonies and during only 6 of 197 inspections. No wax moths were seen, not even in hives that sat unoccupied for one $(n=9)$ or two $(n=2)$ summers.

\section{DISCUSSION}

The main aim of this study was to determine whether the life-history traits of wild colonies 


\begin{tabular}{|c|c|c|c|c|c|c|}
\hline Site & $\begin{array}{l}2011 \\
M J S\end{array}$ & $\begin{array}{c}2012 \\
\text { M J S }\end{array}$ & 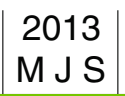 & $\left|\begin{array}{c}2014 \\
\text { M J S }\end{array}\right|$ & $\begin{array}{c}2015 \\
\text { M J S }\end{array}$ & $\begin{array}{l}2016 \\
M\end{array}$ \\
\hline Gibson Place & $\begin{array}{ll}0 & 0 \\
& \\
& 19\end{array}$ & $\begin{array}{ccc}0 & & \\
15 & 5 & 18\end{array}$ & 121 & $8 \begin{array}{lll}8 & 10 & 74\end{array}$ & & \\
\hline Tree House & $\begin{array}{rr}0 & 0 \\
18 & \end{array}$ & $\begin{array}{lll}0 & & \\
3 & 3 & 21\end{array}$ & 2283252 & & & \\
\hline Kendal Garden & $\begin{array}{ll}0 & 0 \\
25\end{array}$ & $\begin{array}{l}0 \\
11\end{array}$ & 12 & 024112 & & \\
\hline Gussie's Meadow & $\begin{array}{ll} & 0 \\
& \\
& 44\end{array}$ & $\begin{array}{lll}0 & 0 & \\
2 & 1 & 8\end{array}$ & 136 & $\begin{array}{lll}7 & 16 & 70\end{array}$ & $\begin{array}{lll}5 & 4 & 20\end{array}$ & . \\
\hline Mount Pleasant & $\begin{aligned} & 0 \\
& 0 \\
& 34\end{aligned}$ & 2380 & & $\mid \begin{array}{lll}0 & 13 & 16 \\
3 & 13 & 16\end{array}$ & $5 \begin{array}{ccc} & ? & 3 \\
5 & 12 & 39\end{array}$ & \\
\hline USDA Building & & 30134 & 629 & $\begin{array}{llll} & & & \\
3 & 4 & 22\end{array}$ & $\begin{array}{llll}7 & 10 & 45\end{array}$ & $\tau$ \\
\hline Railroad Grade & & $\begin{array}{lll}0 & 0 & 0 \\
23100\end{array}$ & 2496 & & & \\
\hline Judd Falls & & $\begin{array}{lll}0 & 0 & 0 \\
& 8 & 28\end{array}$ & $\begin{array}{lll}0 & 0 & \\
5 & 7 & 21\end{array}$ & $\begin{array}{lll}0 & ? & 0 \\
2 & 0 & 1\end{array} \mid$ & $\begin{array}{lll}7 & 3 & 26\end{array}$ & 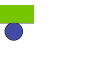 \\
\hline Van Pelt Woods & & 3856 & $\begin{array}{llll}3 & 10 & 21\end{array}$ & $\left|\begin{array}{ccc}0 & ? & 0 \\
1 & 15 & 14\end{array}\right|$ & $\begin{array}{lll}6 & 10 & 17\end{array} \mid$ & \\
\hline Myer's Farm & & 1110 & $\begin{array}{lll}3 & 7 & 16\end{array}$ & $\begin{array}{ll}4 & 17\end{array}$ & & \\
\hline Sienko Barn & & $\begin{array}{cc}0 & 0 \\
15 & 29\end{array}$ & & $\begin{array}{ll}3 & 20 \\
3 & \end{array}$ & $\begin{array}{llll}4 & 15 & 27\end{array}$ & $\tau$ \\
\hline CCC Camp & & $\begin{array}{ll}6 & 32 \\
6\end{array}$ & \begin{tabular}{lll|} 
& $?$ & \\
0 & 1 & 10
\end{tabular} & {$\left[\begin{array}{lll}0 & ? & \\
8 & 9 & 39\end{array}\right.$} & {$\left[\begin{array}{lll}0 & 0 & \\
6 & 3 & 14\end{array}\right.$} & 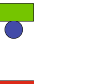 \\
\hline MacDaniels Grove & & 850 & $\begin{array}{lll}0 & ? & 0 \\
1 & 4 & 20\end{array}$ & 1035103 & & \\
\hline Game Farm & & $\begin{array}{ll}5 & \\
5 & 2\end{array}$ & 248 & 1224 & $\begin{array}{llll}3 & 39 & 18\end{array}$ & 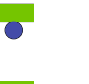 \\
\hline Stevenson Road & & $\begin{array}{cc}0 & 0 \\
13 & 40\end{array}$ & $\begin{array}{llll}0 & 0 & \\
2 & 2 & 31\end{array}$ & $\begin{array}{lll}8 & & \\
8 & 4 & 8\end{array}$ & $\begin{array}{lll}0 & ? & \\
1 & 9 & 14\end{array}$ & $\sigma$ \\
\hline Ellis Hollow Creek & & & $\begin{array}{ll}0 & \\
5 & 55\end{array}$ & $\begin{array}{|lll|} & & \\
1 & 2 & 8\end{array}$ & $\begin{array}{lll} & & 0 \\
0 & 2 & 9\end{array}$ & 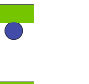 \\
\hline Varna & & & $\begin{array}{lll} & \\
0 & 53 \\
\end{array}$ & 22 & $\begin{array}{llll}0 & ? & \\
5 & 14 & 19\end{array}$ & 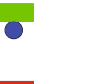 \\
\hline Gallus Road & & & 1248 & 1438 & & \\
\hline Day Lilies & & & $\begin{array}{ll} & 0 \\
1 & 16\end{array}$ & $\begin{array}{llll}8 & 14 & 68\end{array}$ & & \\
\hline Cat House & & & \begin{tabular}{ll|l|} 
& & \\
2 & 12 & 1 \\
\end{tabular} & $\mid \begin{array}{lll}11 & 1 & 12\end{array}$ & $\begin{array}{ccc}0 & 0 & 0 \\
1 & 9 & 23\end{array}$ & 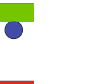 \\
\hline Radio Tower & & & $\begin{array}{ll} & 2 \\
3 & 29\end{array}$ & 1735 & & \\
\hline Hurd Road & & & $\begin{array}{ll}0 \\
1 & 9\end{array}$ & $\begin{array}{ll}123 \\
\end{array}$ & & \\
\hline
\end{tabular}

Figure 3. Results from a 6-year program of inspecting 22 hives occupied by simulated wild colonies. Inspections made in early May, late July, and late September. Colored bars indicate type of colony, as in Fig. 2. Colored circles show colors of paint marks on queens. A question mark indicates a time when queen was not found, probably because a virgin queen. Numbers indicate how many Varroa mites were caught on sticky board in $48 \mathrm{~h}$. 
Table II. Survivorship probabilities of simulated wild colonies over summers and winters, for 2011-2016

\begin{tabular}{|c|c|c|c|c|c|}
\hline \multicolumn{3}{|c|}{ Summer } & \multicolumn{3}{|l|}{ Winter } \\
\hline \multicolumn{3}{|c|}{ (10 May-20 Sept) } & \multicolumn{3}{|c|}{ (20 Sept-10 May) } \\
\hline Year & Founder & Established & Year & Founder & Established \\
\hline 2011 & $1.00(n=5)$ & nd & $2011-12$ & $0.80(n=5)$ & nd \\
\hline 2012 & $1.00(n=11)$ & $1.00(n=4)$ & $2012-13$ & $0.54(n=11)$ & $0.75(n=4)$ \\
\hline 2013 & $1.00(n=12)$ & $1.00(n=9)$ & 2013-14 & $0.50(n=12)$ & $0.78(n=9)$ \\
\hline 2014 & $1.00(n=7)$ & $1.00(n=13)$ & $2014-15$ & $0.43(n=7)$ & $0.69(n=13)$ \\
\hline 2015 & nd & $1.00(n=12)$ & $2015-16$ & nd & $0.92(n=12)$ \\
\hline Mean & 1.00 & 1.00 & Mean & 0.57 & 0.79 \\
\hline
\end{tabular}

nd no data

living near Ithaca, NY, have changed now that they must invest in immunological, behavioral, and other defenses against $V$. destructor and associated viruses. Table III summarizes the findings reported here for 2010-2016 and those reported previously (Seeley 1978) for 1974-1977. The two sets of findings are strikingly similar even
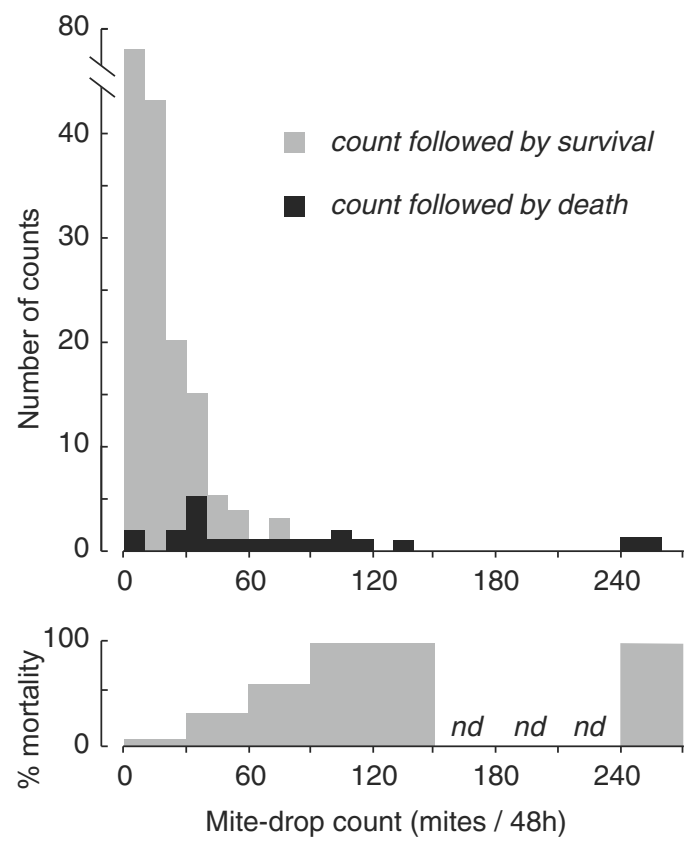

Figure 4. Top: distribution of 177 mite-drop counts made during the thrice annual inspections of 35 simulated wild colonies. Bottom: colony mortality in relation to the mite-drop count of the previous inspection. though they were made ca. 20 years before and ca. 20 years after the arrival of $V$. destructor. Both sets of results show that most newly founded colonies and established colonies survive summers, but that only ca. $26 \%$ of founder colonies and ca. $82 \%$ of established colonies survive winters. Both sets of results also show that founder colonies rarely change queens/produce swarms, but that established colonies are likely to do so $(p=0.96$ for 1970s and $p=0.87$ for 2010s). Furthermore, the 1970s and 2010s results yield almost identical estimates of mean colony lifespan: 2.1 and 2.2 years for all colonies and 5.6 and 6.2 years for established colonies. Evidently, the wild colonies living near Ithaca have essentially the same suite of life-history traits in 2010s as in 1970s: slow development, long lifespan once established, and few but costly offspring.

A model of the dynamics of both the 1970s and 2010s populations (Figure 5) predicts a stable population of colonies for both times. Evidently, the persistence of this wild colony population in the past, and still today, reflects strong reproduction by established colonies, which nearly doubles the population over summer, followed by high mortality of newly-founded colonies and low mortality of established colonies, which approximately halves the population over winter.

How can we explain the finding that wild colonies in the 1970s and the 2010s have essentially identical sets of life-history traits, even though wild colonies in the 2010s must invest in defenses against the introduced parasite $V$. destructor and 
Table III. Probabilities of survival and reproduction (swarming) for wild colonies in 1970s and 2010s

\begin{tabular}{|c|c|c|c|c|c|c|}
\hline & \multicolumn{3}{|c|}{ Summer } & \multicolumn{3}{|l|}{ Winter } \\
\hline & $1970 \mathrm{~s}$ & $2010 \mathrm{~s}$ & & $1970 \mathrm{~s}$ & $2010 \mathrm{~s}$ & \\
\hline \multicolumn{7}{|c|}{ Colony survival } \\
\hline Founder & 0.82 & 1.00 & $p>0.06$ & 0.29 & 0.23 & $p>0.90$ \\
\hline Established & 0.98 & 0.97 & $p>0.90$ & 0.80 & 0.84 & $p>0.80$ \\
\hline \multicolumn{7}{|c|}{ Colony reproduction } \\
\hline Founder & 0.00 & 0.09 & $p>0.50$ & 0.00 & 0.00 & $p=1.00$ \\
\hline Established & 0.95 & 0.87 & $p>0.39$ & 0.00 & 0.00 & $p=1.00$ \\
\hline
\end{tabular}

associated viruses? Life-history theory predicts that the costs of colony defense are traded off against other colony fitness components, such as growth rate, survivorship, and reproduction (Minchella 1985; Sheldon and Verhulst 1996; Schmid-Hempel 2003). Greater investment in colony defense in the 2010 s relative to that of the 1970s should, therefore, result in slower growth and weaker reproduction, and perhaps reduced survivorship.
One possible explanation for the absence of change in the life-history traits is that the strains of $V$. destructor (and/or the viruses vectored by them) in the wild colonies were not virulent, so these colonies did not need costly defenses against the mites and viruses. It is clear, however, that many of the simulated wild colonies had virulent mites. Every established colony that did not change its queen (by swarming?) over summer developed a fatally high mite population by
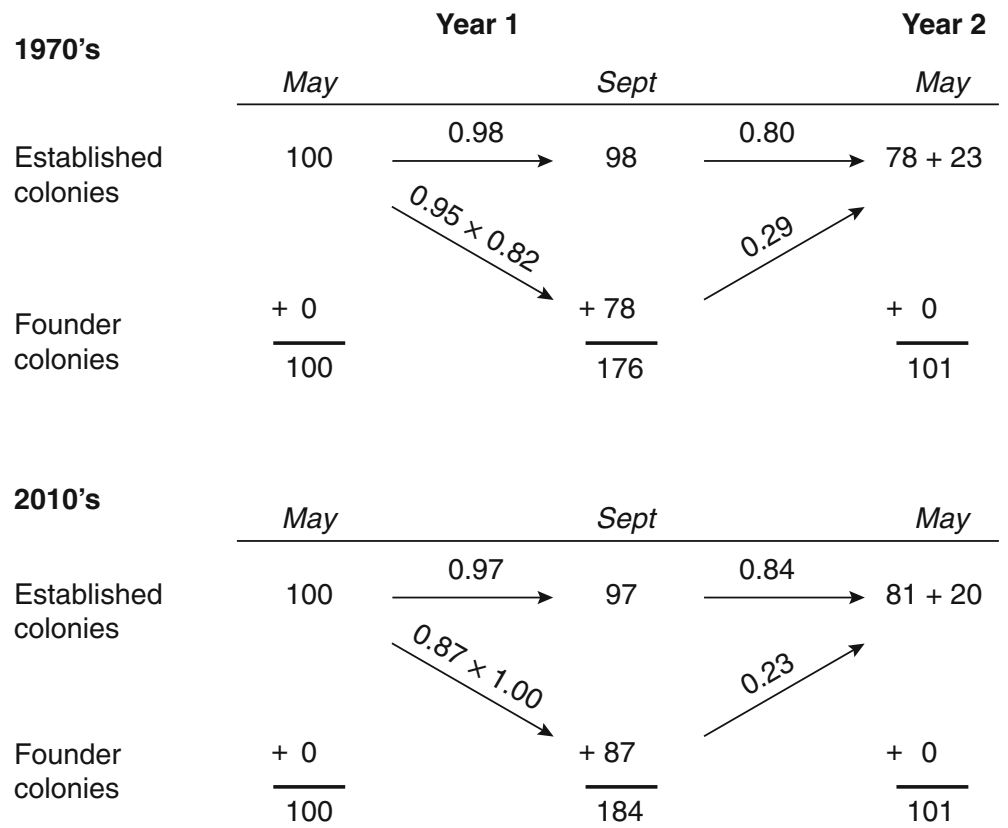

Figure 5. Dynamics in number and type of colonies in a population of wild colonies, starting in May (before swarming), for the 1970s and the 2010s. The population starts with 100 established colonies in early May, year 1. The probabilities of colony survival and colony reproduction over summer (Table III) were used to calculate how many colonies (established and founder) are expected in late September, year 1. Finally, the probabilities of colony survival over winter (Table III) were used to calculate how many established colonies are expected in early May, year 2. 
September (see data for Gibson Place, Tree House, Kendal Garden, MacDaniels Grove, and Day Lilies, Figure 3). Moreover, every colony with a 100+ mite-drop count died (Figure 4), which suggests that the strains of the deformed wing virus (DWV) in the colonies were highly virulent, since it is high virus titers that kill colonies (Martin et al. 2012.) A recent paper (Mordecai et al. 2015) reports, however, that an avirulent variant of DWV exists in some locations in the UK, so perhaps an avirulent variant of DWV also exists in some of the wild colonies near Ithaca, NY. These colonies are widely spaced (Seeley et al. 2015), so the spread of V. destructor and DWV between colonies may occur more by vertical transmission (from parent colony to offspring colony, by swarming) than by horizontal transmission (among unrelated colonies; by drifting, robbing, and foraging; see Peck et al. 2016). If so, then perhaps the mites and viruses in these wild colonies are evolving avirulence (Ewald 1994; Fries and Camazine 2001), but it seems clear that they are not there yet.

The most likely explanation for the absence of change in life-history traits between 1970s and 2010 s is that the wild colonies possess effective, but low-cost, defenses against $V$. destructor and associated viruses. We know that colonies living in the wild occupy small nest cavities and swarm frequently, and that these traits of wild colonies provide them with resistance to Varroa (Loftus et al. 2016). We also know that the leave-aloneand-let-die experiment on Gotland in Sweden (Fries et al. 2003) produced survivor colonies that were much smaller (and more inclined to swarm?) than the original colonies (Locke and Fries 2011; Locke 2016). Furthermore, the present study found that colonies that had a queen change (probably by swarming) ended the summer with much lower mite-drop counts than colonies that lacked a queen change (average 23 vs. 122 mites $/ 48$ h). The mechanisms whereby smaller and swarmier colonies have greater resistance to $V$. destructor are not understood fully, but it is likely that having relatively few brood, especially drone brood, helps control the mites. It is also likely that frequent swarming helps control the mites because a swarming event exports about $35 \%$ of a colony's mites; a colony's workers carry about $50 \%$ of the adult mites (Fuchs 1985) and about $70 \%$ of a colony's workers leave in the prime swarm (Rangel and Seeley 2012). Furthermore, swarming temporarily deprives the mites of pupal brood, and their absence disrupts the mites' reproduction and boosts their exposure to mite-biting bees (Hunt et al. 2016).

It may be, therefore, that certain features of the biology of honey bee colonies living in the wild-such as small colony size and frequent swarming-endow them with good defenses against $V$. destructor, so they have not needed to evolve costly, new defenses against the mites and associated viruses. It may also be, however, that wild colonies have needed to evolve some new defenses against $V$. destructor - including hygienic behavior and grooming behavior — but that these new defenses are not costly. Our next goal is to identify the suite of colony defenses that is enabling this population of wild colonies to persist, for doing so will reveal a natural, nontreatment solution to the problem of $V$. destructor.

\section{ACKNOWLEDGEMENTS}

I thank R. Armstrong, B. Darlington, M. Denver, S. Griffin, S. Henry, A. Kohout, K. Loope, L. Lounsbery, G. Menda, J. Nyrop, D. Peck, J. Phillips, D. Schaufler, M. Seeley, and M. Smith for helping find the 33 nest sites of wild colonies. I also thank D. Peck and M. Smith for critical feedback on the manuscript. This study was supported by Hatch Grants (Projects NYC-191833 and NYC-191400) from the Cornell University Agriculture Experiment Station and by a gift from Katherine Collins/Honeybee Capital.

\section{Contributions None.}

\section{OPEN ACCESS}

This article is distributed under the terms of the Creative Commons Attribution 4.0 International License (http://creativecommons.org/licenses/by/4.0/), which permits unrestricted use, distribution, and reproduction in any medium, provided you give appropriate credit to the original author(s) and the source, provide a link to the Creative Commons license, and indicate if changes were made. 


\section{APPENDIX 1}

Table IV. Pooled results on wild colony survival in the 1970s and the 2010s

\begin{tabular}{|c|c|c|c|c|}
\hline \multicolumn{5}{|c|}{$1970 \mathrm{~s}$} \\
\hline & \multicolumn{2}{|c|}{ Summer } & \multicolumn{2}{|c|}{ Winter } \\
\hline & Founder & Established & Founder & Established \\
\hline Survived & 14 & 44 & 4 & 35 \\
\hline Died & 3 & 1 & 10 & 9 \\
\hline \multicolumn{5}{|c|}{$2010 \mathrm{~s}$} \\
\hline & & Summer & & Winter \\
\hline & Founder & Established & Founder & Established \\
\hline Survived & 26 & 76 & 5 & 54 \\
\hline Died & 0 & 3 & 15 & 11 \\
\hline
\end{tabular}

Shown are the total numbers of colonies that survived or died over the summer or over the winter across two time periods: 1970 1974 and 2010-2016

\section{APPENDIX 2}

Table V. Pooled results on simulated wild colony survival in the 2010s

2010 s

\begin{tabular}{|c|c|c|c|c|}
\hline & \multicolumn{2}{|l|}{ Summer } & \multicolumn{2}{|l|}{ Winter } \\
\hline & Founder & Established & Founder & Established \\
\hline Survived & 35 & 38 & 19 & 30 \\
\hline Died & 0 & 0 & 16 & 8 \\
\hline
\end{tabular}

Shown are the total numbers of colonies that survived or died over summer or over winter across the time periods of 2010-2016

Caractéristiques du cycle évolutif de colonies d'abeilles sauvages vivant dans les forêts entourant Ithaca, NY, USA

Apis mellifera / évolution du cycle biologique / survie de la colonie / virus des ailes déformées / Varroa destructor

Merkmale im Lebenszyklus von wildlebenden Honigbienenvölkern in den Wäldern von Ithaka, USA

Apis mellifera / Überleben von Bienenvölkern / Deformierter Flügel-Virus / Varroa destructor / wildlebende Honigbienen / Lebenszyklus-Evolution

\section{REFERENCES}

Ewald, P.W. (1994) Evolution of infectious disease. Oxford University Press, Oxford.

Fell, R.D., Ambrose, J.T., Burgett, D.M., DeJong, D., Morse, R.A., Seeley, T.D. (1977) Seasonal cycle of swarming in honey bees (Apis mellifera L.). J. Apic. Res. 16, 170-173

Fries, I., Camazine, S. (2001) Implications of horizontal and vertical pathogen transmission for honey bee epidemiology. Apidologie 32, 199-214

Fries, I., Hansen, H., Imdorf, A., Rosenkranz, P. (2003) Swarming in honey bees (Apis mellifera) and Varroa 
destructor population development in Sweden. Apidologie 34, 389-397

Fries, I., Imdorf, A., Rosenkranz, P. (2006) Survival of mite infested (Varroa destructor) honey bee (Apis mellifera) colonies in a Nordic climate. Apidologie 37, 564-570

Fuchs, S. (1985) Untersuchungen zur quantitativen Abschätzung des Befalls von Bienenvölkern mit Varroa jacobsoni OUD. und zur Verteilung des Parasitenim Bienenvolk. Apidologie 16, 343-368

Hansen, H. (1987) Honey bee brood diseases. Wicwas Press, Ithaca, New York

Hunt, G., Given, J.K., Tsuruda, J.M., Andino, G.K. (2016) Breeding mite-biting bees to control Varroa . Bee Culture 8, 41-47

Korpela, S., Aarhus, A., Fries, I., Hansen, H. (1992) Varroa jacobsoni Oud. in cold climates: population growth, winter mortality and influence on survival of honey bee colonies. J. Apic. Res. 31, 157-164

Le Conte, Y., de Vaublanc, G., Crauser, D., Jeanne, F., Rousselle, J.-C., Bécard, J.-M. (2007) Honey bee colonies that have survived Varroa destructor. Apidologie 38, 566-572

Locke, B. (2016) Natural Varroa mite-surviving Apis mellifera honeybee populations. Apidologie 47, 467-482

Locke, B., Fries, I. (2011) Characteristics of honey bee colonies (Apis mellifera) in Sweden surviving Varroa destructor infestation. Apidologie 42, 533-542

Loftus, J.C., Smith, M.L., Seeley, T.D. (2016) How honey bee colonies survive in the wild: testing the importance of small nests and frequent swarming. PLoS ONE 11, e0150362. doi:10.1371/journal.pone.0150362

Martin, S.J., Highfield, A.C., Brettell, L., Villalobo, E.M., Budge, G.E., et al. (2012) Global honey bee viral landscape altered by a parasitic mite. Science 336, 1304-1306

Mikheyev, A.S., Tin, M.M.Y., Arora, J., Seeley, T.D. (2015) Museum samples reveal rapid evolution by wild honey bees exposed to a novel parasite. Nature Comm. 6, 7991. doi 10.1038/ncomms8991

Minchella, D.J. (1985) Host life-history variation in response to parasitation. Parasitology 90, 205-216.
Mordecai, G.J., Brettell, L.E., Martin, S.J., Dixon, D., Jones, I.M., Schroeder, D.C. (2015) Superinfection exclusion and the long-term survival of honey bees in Varroa -infested colonies. ISMEJ 2015, 1-10

Moritz, R.F.A., Kraus, B., Kryger, B., Crewe, R.M. (2007) The size of wild honey bee populations (Apis mellifera ) and its implications for the conservation of honeybees. J. Insect Conserv. 11, 391-39

Peck, D.M., Smith, D.L., Seeley, T.D. (2016) Varroa destructor mits can nimbly climb from flowers onto foraging honey bees. PLoS ONE 11 (12): e0167798

Potts, S.G., Biesmeijer, J.C., Kremen, C., Neumann, P., Schweiger, O., Kuning, W.E. (2010) Global pollinator declines: trends, impacts, and drivers. Trends Ecol. Evol. 25, 345-353

Rangel, J., Seeley, T.D. (2012) Colony fissioning in honey bees: size and significance of the swarm fraction. Insectes Soc. 59, 453-462

Schmid-Hempel, P. (2003) Variation in immune defence as a question of evolutionary ecology. Proc. R. Soc. Lond. B 270, 357-366

Seeley, T.D. (1978) Life history strategy of the honey bee, Apis mellifera. Oecologia 32, 109-118

Seeley, T.D. (2007) Honey bees of the Arnot Forest: a population of feral colonies persisting with Varroa destructor in the northeastern United States. Apidologie 38, 19-29

Seeley, T.D. (2016) Following the wild bees. The craft and science of bee hunting. Princeton University Press, Princeton

Seeley, T.D. Morse, R.A. (1976) The natural nest of the honey bee (Apis mellifera). Insectes Soc. 23, 495-512

Seeley, T.D., Tarpy, D.R., Griffin, S.R., Carcione, A., Delaney, D.A. (2015) A survivor population of wild colonies of European honeybees in the northeastern United States: investigating its genetic structure. Apidologie 46, 654-666

Sheldon, B.C., Verhulst, S. (1996) Ecological immunology: costly parasite defences and trade-offs in evolutionary ecology. Trends Ecol. Evol. 11, 317-321 